\title{
Education for a Sustainable Future
}

A Paradigm of Hope for the 21st Century 


\section{INNOVATIONS IN SCIENCE EDUCATION AND TECHNOLOGY}

Series Editor:

Karen C. Cohen, Harvard University, Cambridge, Massachusetts

Are Schools Really Like This?: Factors Affecting Teacher Attitude toward School Improvement

J. Gary Lilyquist

Education for a Sustainable Future: A Paradigm of Hope for the 21st

Century

Edited by Keith A. Wheeler and Anne Perraca Bijur

The Hidden Curriculum-Faculty-Made Tests in Science

Part 1: Lower-Division Courses

Part 2: Upper-Division Courses

Sheila Tobias and Jacqueline Raphael

Internet Links for Science Education: Student-Scientist Partnerships

Edited by Karen C. Cohen

Science, Technology, and Society: A Sourcebook on Research and

Practice

Edited by David D. Kumar and Daryl E. Chubin

Time for Science Education

Michael R. Matthews

Web-Teaching: A Guide to Designing Interactive Teaching for the World Wide Web

David W. Brooks

A Continuation Order Plan is available for this series. A continuation order will bring delivery of each new volume immediately upon publication. Volumes are billed only upon actual shipment. For further information please contact the publisher. 


\title{
Education for a Sustainable Future
}

\section{A Paradigm of Hope for the 21st Century}

\author{
Edited by \\ Keith A. Wheeler and Anne Perraca Bijur \\ The Center for a Sustainable Future \\ a division of the Concord Consortium \\ Shelburne, Vermont and Concord, Massachusetts
}

Springer Science+Business Media, LLC 
ISBN 978-0-306-46420-1 ISBN 978-1-4615-4277-3 (eBook)

DOI 10.1007/978-1-4615-4277-3

(C)2000 Springer Science+Business Media New York

Originally published by Kluwer Academic/Plenum Publishers in 2000

All rights reserved

No part of this book may be reproduced, stored in a retrieval system, or transmitted in any form or by any means, electronic, mechanical, photocopying, microfilming, recording, or otherwise, without written permission from the Publisher. 
To Courtney and Ross Wheeler and to Oliver Bijur

May their lives and the lives of their children be filled with the Hope, Passion, and the Opportunity to create a truly Sustainable Future! 


\section{Contributors}

Richard Benjamin, Superintendent, Cobb County Public Schools, Marietta, GA

Jack Byrne, Program Director, Center for a Sustainable Future, Shelburne, VT

Mark DiMaggio, High School teacher of Earth and Environmental Sciences, Paso Robles High School, Paso Robles, CA

John Fien, Faculty of Environmental Sciences, Griffith University, Brisbane, Australia

Cynthia Georgeson, Director Worldwide Communications, S.C. Johnson Corp., Racine, WI

Wendy Goldstein, Head Environmental Education \& Communication, IUCN, Gland, Switzerland

Susan Hanes, Director of the Metro Atlanta P-16 Council, Georgia State University, Atlanta, GA

Frits Heselink, Chairman, Commission on Education and Communication, IUCN, Gland, Switzerland

Rupert Maclean, Chief, Asia-Pacific Centre of Educational Innovation for Development UNESCO, Principal Regional Office for Asia and the Pacific, Bangkok, Thailand 
Jean MacGregor, Director, National Learning Communities Dissemination Project, The Washington Center for Improving the Quality of Undergraduate Education at The Evergreen State College, Olympia, WA

M. Patricia Morse, Professor of Biology, University of Washington, Seattle, WA

Lynn Mortenson, Director Education and Outreach, U.S. Global Change Research Program, Washington, D.C.

Mary Paden, Resource Center Director, Academy for Educational Development, Washington, D.C.

Anne Perraca Bijur, Coordinator, Building Education for a Sustainable Society, Shelburne Farms, Shelburne, VT

Jean Perras, Executive Director, Learning for a Sustainable Future, Ottawa, Ontario, Canada

Larry Peterson, Director, Florida Sustainable Communities Network, Florida A\&M, Tallahassee, FL

Alan Sandler, Executive Director, Architectural Foundation of San Francisco, San Francisco, CA

Michael Schneider, Dean, Washington Program-Maxwell School of Business, Syracuse University, Washington, D.C.

Bradley Smith, Dean, Huxley College, Western Washington Univ. Bellingham, WA

Keith Wheeler, Director, Center for a Sustainable Future, Shelburne, VT

Lori Wingerter, Coordinator, Community Impact Team, General Motors Corporation, Detroit, MI 


\section{Foreword}

WHY EDUCATE FOR SUSTAINABILITY?

Ask most people-especially young people-what the future looks like to them. They will paint for you a rosy picture of their individual lives, their future homes, their careers and sometimes even the lives of their children. Then they will paint for you a depleted, conflicted and weary picture of the planet as a whole. Do any of us note the incongruence? We are becoming increasingly aware that the very things we need, the things we adore most in this world are the very things we are undermining through our individual and collective behaviors. We can feel the disconnect between the consequences of our actions and our values, but we do not necessarily understand it or know how to reconcile it.

Living with behavior that feels, and in fact is, inconsistent with our values is a recipe for anguish. We have disconnected so drastically from our sense of place that ironically we poison our water, our air, and our food while at the same time we work hard to secure a healthy and meaningful future for ourselves and our children. This just doesn't make sense.

Hope is the union of a vision with the capacity to realize it. Education for sustainability helps us to create optimistic visions and develops in us the capacity for actions that are consistent with those visions. It makes sense for us to cultivate hope in our children for themselves and for the world around them. What would be the point of being educated for a future for which we have no hope?

Another reason to educate for sustainability is that it is the ethical thing to do. Aldo Leopold wrote: "All ethics so far evolved rest upon a single premise: that the individual is a member of a community of interdependent 
parts. His instincts prompt him to compete for his place in the community but his ethics prompt him also to co-operate (perhaps in order that there may be a place to compete for)." Simply put, it is the right thing to do.

Finally those of us who have already been provoked to educate for sustainability continue to do so because it is the most ambitious, creative, elegant, innovative, out of the box, exhilarating, difficult, frustrating, comprehensive, enlightening, rewarding, holistic, ego-boosting, and humbling work there is to do. And we would not miss it for the world.

Whoever you are and whatever compels you to move, to grow, and to change, this book is an invitation to you to learn, and to educate for a sustainable future.

Jamie P. Cloud, Founder and Director The Sustainability Education Center New York, NY 


\section{Preface to the Series}

The mandate to expand and improve science education is an educational imperative and an enormous challenge. Implementing change, however, is very complicated given that science as well as science education is dynamic, continually incorporating new ideas, practices, and procedures; takes place in varying contexts; and must deal with amazingly rapid technological advances. Lacking clear paths for improvement, we can and should learn from the results of all types of science education, traditional as well as experimental. Successful reform of science education requires careful orchestration of a number of factors which take into account technological developments, cognitive development, societal impacts and relationships, organizational issues, impacts of standards and assessment, teacher preparation and enhancement, as well as advances in the scientific disciplines themselves. Understanding and dealing with such a complex mission is the focus of this book series. Each book in this series deals in depth with one or more of these factors, these potential factors for understanding, creating and sustaining effective science education improvement and reform.

In 1992, a multidisciplinary forum was launched for sharing the perspectives and research findings of the widest possible community of people involved in addressing the challenge. Those who had something to share regarding impacts on science education were invited to contribute. This forum was the Journal of Science Education and Technology. Since the inception of the journal, many articles have highlighted relevant themes and topics and expanded the context of understanding to include historical, current, and future perspectives in an increasingly global context. Recurring topics and themes have emerged as foci requiring expanded treatment 
and presentation. This book series, "Innovations in Science Education and Technology" is the result.

It is a privilege to be able to continue to elucidate and effect improvement and reform in science education by providing this in-depth forum for the works of others. The series brings focus and understanding to efforts worldwide, helping readers to understand, to incorporate, and to utilize what we know, what we are learning, and what we are inventing technologically to advance the mission of science education reform worldwide.

Karen C. Cohen

Cambridge, Massachusetts 


\section{Contents}

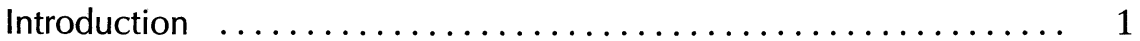

Keith Wheeler

Sustainability from Five Perspectives $\ldots \ldots \ldots \ldots \ldots, 2$

Chapter 1. Education for Sustainability and Environmental

Education ............................ 7

Mary Paden

Chapter 2. Global Change Education: Educational Resources

for Sustainability ..................... 15

Lynn L. Mortensen

Transition ........................... 16

International Agreements $\ldots \ldots \ldots \ldots \ldots \ldots \ldots, 18$

Global Change Education and Sustainability ....... 20

Systemic Change ...................... 22

Education Products/Resources $\ldots . \ldots \ldots \ldots \ldots . \ldots 23$

Professional Development ................. 24

Student Support ....................... 25

Lessons Learned ......................... 25

The National Assessment .................... 27

Informed Decision Making $\ldots \ldots \ldots \ldots \ldots \ldots . \ldots 27$

Concluding Comment ...................... 29

Resources ............................. 29

References .......................... 33 
Chapter 3. From Policy to Practice: Creating Education for a Sustainable Future $\ldots \ldots \ldots \ldots \ldots \ldots \ldots \ldots, 35$

Jack Byrne

Building a Foundation for Sustainability Education ... . 37 Developing the Materials and Technology Tools for Learning and Teaching Sustainable Development during the First Nine Months of the Project $\ldots \ldots \ldots 42$ Appendix 1. Education for a Sustainable Future: Overall Essential Learnings-A Broad Brush ...... 49 Appendix 2. Chat Excerpt ................. 53 Appendix 3. ESF Software ................. 57

Appendix 4. Unit Design Rubric ................ 67 References......................... 72

Chapter 4. Educating for Sustainability in American High Schools .............................. 73

Mark DiMaggio

Portrait of an American High School Student ....... 74 Portrait of the System in which the Student

Operates .......................... 76

Sustainability as an Integrating Theme $\ldots \ldots \ldots \ldots . \ldots 77$

A 10 Year Classroom Experiment ............. 78

Going School-Wide with Sustainability Education .... 80

Conclusions ........................ 81

Chapter 5. The Role of Higher Education in Sustainable Development Education .................. 83

Bradley F. Smith

Chapter 6. Teacher Education for Sustainability: Two Teacher Education Projects from Asia and the Pacific ........ 91 John Fien and Rupert Maclean

The Priority of Priorities .................. 92

Addressing a History of Neglect ................ 94

Teaching for a Sustainable World $\ldots \ldots \ldots \ldots \ldots \ldots 96$

The Learning for a Sustainable Environment-

Innovations in Teacher Education Project . . . . . . . 100

Conclusion ................................ 109

References .............................. 109

Extra References $\ldots \ldots \ldots \ldots \ldots \ldots \ldots \ldots \ldots . \ldots 111$ 
Chapter 7. Education for Understanding Science and the Earth System for Long-Term Sustainability

M. Patricia Morse

Introduction ........................... 113

Background ................................ 114

Science for Sustainability . . . . . . . . . . . . . . . . . 119

Science Pathways ....................... 120

Education Pathways ...................... 121

References ........................... 122

Chapter 8. The Role of IUCN-the World Conservation

Union-in Shaping Education for Sustainability ...... 123

Frits Heselink and Wendy Goldstein

Background of IUCN .................. 123

The Commission on Education and Communication

CEC ................................. 124

Broadening the Conservation Focus to Sustainability:

An International Framework ................. 125

Educating for Sustainable Living $\ldots \ldots \ldots \ldots \ldots \ldots . \ldots 126$

Promoting Communication and Education as

Integrated Policy Instruments $\ldots \ldots \ldots \ldots \ldots \ldots \ldots 131$

Promoting a Focus on Key Groups Who Can

Influence the Issue ....................... 132

Raise the Issue of Education for Sustainability

Higher on the Government's Agenda . . . . . . . . . . 134

Biodiversity Education \& Communication Policy

Advice ............................... 136

Conclusion ............................... 139

References ............................ 140

Chapter 9. Exploring Sustainable Communities ............. 143 Mary Paden

A Community Vision for Anoka in the Year 2010:

A Unique Community ................... 147

Importance of Human Resources . . . . . . . . . . . . 147

Economy and Opportunity .................. 148

Value of the Natural Environment . . . . . . . . . . . . 148

Services for Quality of Life ................ 149

John Jay High School, Katonah-Lewisboro School

District, New York .......................... 149 
Chapter 10. Facilitating Education for Sustainable

Development .......................... 155

Jean Perras

The Strategy of a Canadian Non-Governmental

Organization

Chapter 11. Transforming Public Education: Sustaining the

Roots of American Ideals, Our Economy, and Our

Environment

Richard Benjamin and Susan Hanes

Sustainability of What? Systems Have Purposes ...... 163

A Discussion of an Emerging Transformation of

A Public School District .................... 165

Reform or Transformation: Them or Us ......... 166

The What and How of Public School Improvement:

What Are the Parts and How Are they Related? . . . . 168

The Big Picture ...................... 170

Paradigm Shift 1-Focus on Results-The Heart of

The Matter-Increase Student Achievement ........ 171

Paradigm Shift 2-Make Effective and Efficient Use

of Resources through an Environment of

Continuous Improvement $\ldots \ldots \ldots \ldots \ldots \ldots \ldots . \ldots 184$

Paradigm Shift 3-Improve Stakeholder Satisfaction,

Emphasing Communication, Responsiveness,

Involvement, and Accountability . . . . . . . . . . . . . 189

Conclusion ............................... 195

References ................................ 197

Chapter 12. Learning Communities: Vehicles for Learning

Community and Sustainability ................. 199

Jean MacGregor

Learning Communities-A Growing National

Reform Effort ...................... 200

Introducing Sustainability through the Disciplines:

The Positive Futures Interdisciplinary Project at

Oakland Community College ............... 202

Pragmatic Visions in the Face of Complexity: The

Studies in Alternative Future Environments (SAFE)

Program at George Mason University ............ 205 
Linking Sustainability to Community Development and Social Justice: The Community Development Coordinated Studies Program at the Evergreen

State College ......................... 207

Visions ................................. 213

References .............................. 214

Chapter 13. Sustainable Development: Visioning and Planning .... 215 Alan Sandler

Sustainable Development .................. 215

Planning and Visioning .................... 216

Visioning for the Future ................... 218

Tips for Vision-Building $\ldots \ldots \ldots \ldots \ldots \ldots \ldots \ldots 219$

Chapter 14. Understanding Sustainable Communities $\ldots \ldots \ldots . .221$ Larry Peterson

1. Defining "Sustainable" and "Communities" ...... 221

2. A Sustainable Community is Defined by

Successful Relationships among Three Interlocking

Sectors: Economy, Society, and Environment ...... 225

3. The Built Environment Both Serves Human

Activities and Limits them through Structural

Constraints ......................... 230

4. Formal Educational Processes Must Support the

Non-Formal and Informal Learning that Takes

Place in a Community .................... 233

References ........................236

Chapter 15. General Motors Role in Education for

Sustainability

Lori Wingerter

The GM Framework: The Foundation $\ldots \ldots \ldots \ldots 238$

The GM Framework: Our Employees-Present and

Future ............................. 239

The GM Framework: Our Suppliers, Our Dealers,

Our Customers ......................... 241

The GM Framework: Collaborative Initiatives ...... 242

The GM Framework: Community Engagement ...... 243

The GM Framework: Learning from the Past,

Building on the Present, Looking to the Future ...... 245 
Chapter 16. Partnerships for Progress A Case Study from SC Johnson

Cynthia Georgeson

Teaching Kids to Shop Smart $\ldots \ldots \ldots \ldots \ldots \ldots 248$

Closing the Gap between Concern and Responsible Action ............................ 248

Redefining the Role of Business in Society ....... 250

Building a Sustainable Community ............ 250

Business Community Must Support Sustainable

Education ........................... 251

Chapter 17. Security and Sustainability: A Secure Nation in a Sustainable World ....................... 253

Michael Schneider

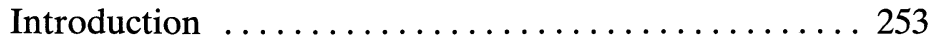

The Changing Face of World Affairs ............ 254

Major Global Issues for the Advent of the New

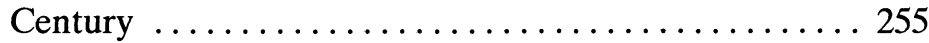

Current U.S. Strategy . . . . . . . . . . . . . . . . . 259

Why Sustainability? .................... 259

Toward a Broader Definition of National Security .... 260

The Need to Shape a Sustainable Strategy for

National Security ..................... 262

The Need for New, Cross-Cutting Strategies . . . . . . . 264

Practical Steps to Build the Capacity for

Sustainability ....................... 267

A Secure Nation in a Sustainable World ......... 268

About the Editors ................................. 269

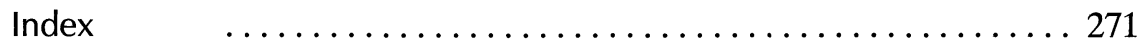

